\title{
THE IMPORTANCE OF THE ROLE OF LANGUAGE IN FOSTERING MULTILINGUALISM IN EDUCATIONAL CONTEXTS IN SOUTH AFRICA
}

JM Baker

In a multilingual society such as ours, all teachers play an integral part in the language acquisition of the learners from pre-school level right up to matric. Teaching content subjects in the mother tongue of the learner is of great importance in his/her acquisition of other languages, especially majority or high-status languages. In the wider society, there is a need for language workers, particularly in urban areas where there is a great diversity of languages. The implication is that changes will have to take place in the curricula of schools and tertiary education institutions. The starting point, however, should be the early years of schooling. More people should be enabled to speak indigenous languages and all people should be able to pursue education in their L1. Teachers who are currently employed could do in-service training to cope with new demands and to enable them to understand the importance of multilingualism. Parallel medium schools and language centres, such as Australia is using, would go a long way towards giving all language groups equal opportunities.

In 'n veeltalige samelewing soos ons s'n speel alle onderwysers ' $n$ integrale deel in leerders se taalverwerwing, van die voorskoolse vlak tot by matriek. Die onderrig van inhoudsvakke in die leerder se moedertaal is van groot belang in sy/haar aanleer van ander tale, veral die hooftale of tale met 'n hoë status. Daar bestaan 'n behoefte aan taalwerkers in die breër samelewing, veral in stedelike gebiede waar groot taaldiversiteit bestaan. Die implikasie is dat daar veranderinge in die kurrikula van skole en inrigtings vir tersiêre opvoeding moet kom. Die beginpunt moet egter die vroeë skooljare wees. Meer mense moet in staat gestel word om inheemse tale te praat, en alle mense moet daartoe in staat wees om hulle opvoeding in hul moedertaal voort te sit. Opvoeders wat tans in diens is, kan indiens-opleiding ontvang ten einde die nuwe eise die hoof te bied en om hulle in staat te stel om die belang van veeltaligheid te begryp. Parallelmediumskole en taalsentra, soos dié in Australië, kan heelwat doen om aan alle taalgroepe gelyke geleenthede te bied.

\section{INTRODUCTION}

The challenges we face today in the "new South Africa" are many and varied. The aim of this paper is to raise some of them and suggest a way of dealing with the challenges that implementing a language policy in which eleven languages are given equal official status will present. 


\section{SOME OF THE CHALLENGES POSED BY THE LANGUAGE POLICY}

At present, South Africa has eleven official languages of unequal status, some of which are spoken as a first language by very small numbers of people (see Table 1 ).

Table 1: Proportional distribution of home languages in each province: 1994

\begin{tabular}{|l|r|r|r|r|r|r|}
\hline Province & Afrikaans & English & \multicolumn{1}{|l|}{ /E } & Ndebele & $\begin{array}{l}\text { Northern } \\
\text { Sotho }\end{array}$ & $\begin{array}{l}\text { Southern } \\
\text { Sotho }\end{array}$ \\
\hline Eastern Cape & $\mathbf{8 , 9 3 \%}$ & $3,86 \%$ & $0,08 \%$ & $0,00 \%$ & $0,01 \%$ & $0,14 \%$ \\
\hline Free State & $\mathbf{1 5 , 0 9 \%}$ & $\mathbf{1 , 5 2 \%}$ & $\mathbf{0 , 1 0} \%$ & $\mathbf{0 , 2 0} \%$ & $\mathbf{0 , 9 2 \%}$ & $\mathbf{5 9 , 2 7 \%}$ \\
\hline Gauteng & $19,72 \%$ & $17,19 \%$ & $0,39 \%$ & $0,85 \%$ & $8,43 \%$ & $11,52 \%$ \\
\hline KwaZulu-Natal & $1,93 \%$ & $16,84 \%$ & $0,07 \%$ & $0,00 \%$ & $0,04 \%$ & $0,35 \%$ \\
\hline Mpumalanga & $\mathbf{8 , 5 7 \%}$ & $1,83 \%$ & $0,08 \%$ & $6,43 \%$ & $15,98 \%$ & $2,79 \%$ \\
\hline North West & $9,00 \%$ & $1,04 \%$ & $0,08 \%$ & $\mathbf{0 , 0 3 \%}$ & $0,73 \%$ & $3,23 \%$ \\
\hline Northern Cape & $68,42 \%$ & $2,74 \%$ & $0,11 \%$ & $0,00 \%$ & $0,13 \%$ & $0,74 \%$ \\
\hline Northern Province & $3,64 \%$ & $0,65 \%$ & $0,02 \%$ & $1,37 \%$ & $62,48 \%$ & $0,91 \%$ \\
\hline Western Cape & $61,81 \%$ & $20,71 \%$ & $0,71 \%$ & $0,00 \%$ & $\mathbf{0 , 0 5 \%}$ & $0,27 \%$ \\
\hline Proportion of total & $14,97 \%$ & $\mathbf{9 , 5 2 \%}$ & $0,19 \%$ & $0,83 \%$ & $9,92 \%$ & $6,83 \%$ \\
\hline
\end{tabular}

\begin{tabular}{|l|r|r|r|r|r|r|r|}
\hline Province & Swazi & Tsonga & Tswana & Venda & Xhosa & Zulu & Other \\
\hline Eastern Cape & $0,00 \%$ & $0,00 \%$ & $0,01 \%$ & $0,00 \%$ & $86,69 \%$ & $0.06 \%$ & $0,17 \%$ \\
\hline Free State & $0,20 \%$ & $0,64 \%$ & $4,81 \%$ & $0,04 \%$ & $9,25 \%$ & $5,99 \%$ & $1,98 \%$ \\
\hline Gauteng & $1,22 \%$ & $3,89 \%$ & $7,38 \%$ & $1,16 \%$ & $6,08 \%$ & $19,36 \%$ & $2.82 \%$ \\
\hline KwaZulu-Natal & $0,03 \%$ & $0,03 \%$ & $0,01 \%$ & $0,00 \%$ & $1,20 \%$ & $78,67 \%$ & $0,82 \%$ \\
\hline Mpumalanga & $25,15 \%$ & $11,52 \%$ & $1,89 \%$ & $0,11 \%$ & $1,45 \%$ & $22,15 \%$ & $2,04 \%$ \\
\hline North West & $0,27 \%$ & $0,81 \%$ & $78,91 \%$ & $0,12 \%$ & $4,18 \%$ & $0,56 \%$ & $1,02 \%$ \\
\hline Northern Cape & $0,01 \%$ & $0,14 \%$ & $19,56 \%$ & $0,01 \%$ & $6,37 \%$ & $0,27 \%$ & $1,50 \%$ \\
\hline Northern Province & $0,32 \%$ & $26,47 \%$ & $1,91 \%$ & $0,01 \%$ & $0,22 \%$ & $0,41 \%$ & $0,59 \%$ \\
\hline Western Cape & $0,01 \%$ & $0,02 \%$ & $0,05 \%$ & $0,00 \%$ & $15,46 \%$ & $0,08 \%$ & $0,82 \%$ \\
\hline Proportion of total & $2,25 \%$ & $4,69 \%$ & $9,07 \%$ & $0,35 \%$ & $18,13 \%$ & $22,00 \%$ & $1,26 \%$ \\
\hline
\end{tabular}

1. The category other refers to, amongst others, Dutch, German, Greek, Italian, Portuguese,

French, Tamil, Hindi, Telegu, Gujarati, Urdu, and Chinese.

2. Figures should add up horizontally but, due to rounding off, might not.

3. The category Ndebele refers to a combined total of home language speakers of Southern and Northern Ndebele.

4. A/E refers to those who speak equal amounts of English and Afrikaans in the home .

As can be seen in the table, there are some areas where one of these languages is spoken by a significant number of people, e.g. Southern Sotho Bloemfontein or Zulu in Kwa-Zulu. In 
those instances, it would be relatively easy to implement a policy whereby two or three regional languages are catered for in public institutions such as hospitals, schools, and regional administration courts. It is not as easy to solve the problems in areas where a larger number of the official languages are represented in sufficient numbers to justify an argument that each of these languages be used in public institutions.

In urban areas, English has become the lingua franca, because it is believed that most people have some knowledge of it. It is widely used in public life, for instance in business, in Parliament, at political rallies and on television. However, most people cannot use it well enough to operate effectively at any sophisticated level. This has serious implications for the proper exercise of people's rights. One bold way of addressing the obvious difficulty many people would have in exercising their democratic rights would be to appoint language workers, i.e. translators and interpreters to work in the frontline all spheres of public life in order to guarantee equity for all. This service would have to cater for the needs of the deaf as well.

In assessing the viability of this suggestion, there are a number of complex questions which need to be addressed. Is it economically possible? Where would all the language workers come from? Is legislation (making the use of such language workers a legal requirement) enforceable? Is it possible to attain true multilingualism? It is beyond the scope of this paper to attempt an exploration of them. In any case, a great deal of complex and thorough-going research would need to be done before-hand. This paper takes a long-term view in focusing on the groundwork that could be done in schools to ensure that the ten of the official languages are not marginalised. In doing so, it draws on research done in South Africa.

\section{THE NEED FOR A LONG-TERM VIEW}

If our country is truly committed to being a multilingual country, with eleven official languages of equal status, then factors such as financial expense and time are obstacle to be overcome rather than reasons for policies not to be implemented.

Where could one best make a start to realising the ideal of equity? Clearly, the long-term view we must take in the South African context makes it best that we begin the campaign for multilingualism in the schools. Self-evidently, children are not born with prejudices in favour or against certain languages, but they grow up in societies where prejudice against those who are different is strong. Pre-school teachers are particularly well placed to play a role in promoting tolerance and generating an interest in languages other than the mother tongue(s) of the learners in a particular school. However, they probably lack the knowledge and skills in order to do so at much more than a superficial level. Assuming that this is the case, preservice teacher education would have to take account of this. An appropriate curriculum would have to draw on a wide range of disciplines. I would suggest anthropology, sociology, two or three additional languages and educational linguistics are the most important of these. The duration of pre-school and junior-primary school teachers (foundation phase) teacher education might even to be lengthened. Use of senior students during their practical teaching in the schools could free teachers to do in-service education courses. If the foundation phase teachers can succeed in fostering an interest in and developing some knowledge of a minority 
or a low status language spoken by some of the children in the school, she would sow the seeds of tolerance and a desire to learn to use other languages.

There is another important aspect which could be addressed. The teacher could not only be involved in generating an interest in other languages but could also, but also elevate the status of a low status or minority language in the eyes of high status L1 speakers as well as low status L1 speakers. This is of very great importance. According to research done by Van Staden (1997), the perceived inferiority of African languages is a major obstacle to multilingualism. Research has long since shown that a positive attitude to one's own language as well as to the target language is necessary for successful language learning. Lambert (1981) points to research done in northern New England with French-American children, where a high regard for their mother tongue as a language of learning enhanced the performance of candidates in English.

If an attitude of tolerance for others and pride in their own culture is not strongly inculcated in our children when they are young, it may be difficult to do so later. It seems that it may also have negative effects on their performance.

Changing attitudes to the low social status of some of the languages will undoubtedly have to be a long-term project with a strong commitment within the schools to this outcome. It is clear, therefore, that the foundation phase teachers will need the support of all the staff. Obviously, since prejudice can be learnt in the home, parents too should ideally be drawn into the shaping process.

\section{ARGUMENTS FOR MULTILINGUALISM}

Researchers such as Hoffman (1991) cite research findings that show that children and adolescents have a strong aptitude for language learning and even very young children have coped with as many as three languages simultaneously. There are a number of reasons which explain their success, and some researchers have even concluded that their youth is the most significant factor. They refer to this as a critical period after which learning a language becomes increasingly difficult. Burling (1981), is among those who have explored the effects of social constraints on adult language learning. His work will be referred to in greater detail later in this article.

Children are less inhibited than adults and achieve native-like competence much more frequently than adults do, therefore it makes good sense to encourage language learning at an early stage, thereby laying the foundation for training future language workers at this level instead of starting at secondary or even tertiary level.

With clear evidence that children are very successful at learning languages, it seems fair to argue that it is not unrealistic to introduce L2 language tuition at the level of basic interpersonal communication skills (BICS) at pre-primary and junior primary schoois where children are drawn from different linguistic backgrounds. If the foundation phase teachers at these schools have received the appropriate training, they will be able to provide the children with what Krashen (1985) terms "comprehensible input", which he considers essential for language acquisition. Since the children will be in a classroom environment where a 
particular L2 is spoken as an L1 by at least some of the children. This should theoretically provide L2 speakers with native speaker input by some of their peers. However, it would be even more desirable for the staff to include teachers with different L1s. This would means that the L2 speakers would have native speaker input by their peers as well as by a teacher, which would enhance the learning process. Ultimately, then, the choice of languages taught in a particular school would depend on the availability of mother-tongue speakers to teach the languages chosen for that school.

\section{ADDITIVE VS SUBTRACTIVE BILINGUALISM}

The kind of bilingualism or multilingualism that should be the outcome of the school curriculum needs to be defined at this stage. Until recently, mother tongue (i.e. an African language) instruction was given up to std 2 (grade 4) in schools that fell under the Department of Education and Training (DET). From std 3 (grade 5) these black pupils had to change to English as the medium of instruction for content subjects. Heugh (1995) sees this kind of bilingual education as undermining the self-concept and cognitive growth of the African language speaking pupil, resulting in subtractive bilingualism, instead of the additive bilingualism of their English and Afrikaans peers (at other schools). The current situation in which African children go to schools which have traditionally used English or Afrikaans as a language of instruction is even worse, because the $\mathrm{Ll}$ of the African pupils is not used as a language of learning at all. This is in strong contrast to the research findings of Lambert (1981) which emphasise the importance of the Lls being elevated to the language of learning up to and even including the secondary level. Cummins (1991) argues that until cognitive language academic proficiency (CALP) has been attained in the L1, a satisfactory transition to the L2 is difficult to make. In other words, once CALP has been achieved in the L1, this ability can be transferred to the L2. De Klerk (1995) adopts a similar position, arguing that children whose $\mathrm{Ll}$ is a marginalised or minority language can not function academically in an L2 which is a majority language or a language of power, until they have attained academic skills in their L1. Here 'minority language' is used to refer to a language without power in the public domain even if it is spoken by a majority of the people. De Klerk's arguments are based on research done by MacDonald and Lanham, who concluded that straight-for-L2 policies are not successful in South Africa. She also quotes research done in the USA by Ramirez over a period of eight years assessing three types of programmes:

\section{Straight-for-English}

2. Early exit bilingual Spanish ( 40 minutes per day for 2 to 3 years)

3. Late-exit bilingual Spanish ( $40 \%$ of the day up to grade 6 ).

The study showed that the Straight-for-English performed weakest and the late exit bilingual schools scored highest when tested in English. De Klerk (1995) refers to research done in South Africa as early as 1938 among Afrikaans-English bilinguals arrived at a similar conclusion.

It seems that bilingualism has a beneficial effect on aspects other than overall academic performance. De Klerk (1995) asserts that bilinguals have a greater capacity to think abstractly than monolinguals because they can distance themselves from a particular language and see things from more than one point of view. They are less bound by words and more elastic in their thinking. 
Ben Zeev (in De Klerk, 1995) claims that bilingual children have greater analytical awareness, because they are constantly organising, analysing and inspecting their languages, which indicates a difference in the way bilinguals process language. De Klerk also analyses quotes research done by Doyle, which concludes that bilinguals are better at relating stories and expressing concepts within those stories. The explanation for this may lie in the work of Ianco-Worrall and Ben Zeev (in Hoffman 1991). They both suggest bilinguals possess a greater sensitivity towards verbal and non-verbal feedback cues. If this is indeed the case, teachers would do well to encourage bilingualism. Sensitivity toward verbal and non-verbal cues would undoubtedly be a valuable asset in school and future vocations.

I would argue further that if bilingual children have an enhanced ability to analyse their own knowledge of language and have greater control of language processing than monolinguals, bilingualism may encourage earlier reading acquisition. This could lead to higher academic achievement.

Not all researchers see consider that bilinguals have significant advantages as opposed to monolinguals (See, for example Hoffman, 1991) do not consider the advantages of bilingualism as opposed to monolingualism to be very significant. However, given the research finding of Cummins (1991), this does not diminish the argument for additive bilingualism in preference to the subtractive bilingualism. Since Lambert (1981), there has been no serious support for the view that bilingualism divides one's cognitive resources and reduces the efficiency of one's thought. Insufficient command of the L2 (English) that has been the outcome for black children for so long.

In my view, additive bilingualism in the South African context can best be brought about by elevating African languages to the highest possible level at school level. Using a black language (where it is the $\mathrm{L} 1$ of particular leamers) as a medium of instruction in content subjects would be one way of establishing its status as a language of learning. The importance of doing so has been argued earlier in this article.

\section{IMPLICATIONS OF USING AFRICAN LANGUAGES}

There would be a number of implications for teachers, lecturers (teacher educators), curriculum planners, linguists, text book authors, school governing bodies and parents. Parents, for instance, could enhance the process at home by affirming their own confidence in the $\mathrm{L} 1$ by speaking it at home, instead of opting for bad English. What they probably view as an attempt to help their children to improve their English, could reinforce a sense that the African language is less important than or even inferior to English. Those parents who are literate and who have access to books in the mother-tongue could encourage their children to read.

Role players involved in the academic sphere could join forces and produce or translate school curricula, policy documents, textbooks and any resource material provided. They could help top develop terminology of the natural sciences, mathematics and other technical subjects, enlisting the help of mother tongue speakers who know these subjects well. This complex and expensive undertaking would have to be a long-term project. A start could be 
made by improving existing material which has been discarded in favour of English material would at least provide interim material up to grade five level until better material has been devised.

Mother-tongue instruction in content subjects would also, of course have implications as far as staff and facilities are concerned. Parallel medium schools may offer a possible solution. Experiments conducted in America with English-Spanish bilingual schools suggest that positive results could be obtained, but as Fishman and Lovas (1972) pointed out long ago, positive community attitudes could be crucial.

The answer for the majority of teachers probably does not lie in initial training. Distance or part-time courses could offer an effective solution for teachers needing additional training to be better-equipped for their task. There is, however, no easy solution to the problems that teachers who are bilingual only in Afrikaans and English, but have to teach pupils whose L1 is an African language. Reference was made earlier to the difficulties adults face in learning a language. Burling's (1981) research is perhaps the most useful in considering some of the difficulties adults face. His experiences in Sweden led him to conclude that the experience of adults leaning a language is very different from that of children. Adults generally have to cope with a much wider range of topics and are expected to have a much larger vocabulary than even high school aged children. Most of the words that adult learners have to cope with are not learned by direct association with events, but require a complex linguistic context. It is normal for small children to name things and events in isolation, but not for adults. Children are given clear instructions on how to be polite (because there are inevitably adult interveners), but adults trying to acquire a language by speaking to adult Ll speakers are unlikely to be told how to be polite. On the other hand, because adults already know at least one language well, they have a high standard by which they judge their progress and can easily become discouraged. An adult is unwilling to restrict himself or herself to childish matters, so at first the goals could appear to be rather daunting., even beyond his or her ability. Native speakers are less likely to repeat, speak slowly and simplify their vocabulary as they would when speaking to children. Adults would rather pretend to have understood than to ask a fourth time. Baby talk; but the broken speech of a foreigner (adult) can be annoying. Children are exposed to a simple form of the target language for hours at a time and are eager to join in games with L1 speakers, but adults are confronted with much less understandable speech for much shorter periods. Clearly, the process is more complex than this, but these are some of the broad social constraints that result in adults making much slower progress than children. It would be unreasonable to expect teachers to try to learn an indigenous language so proficiently that they could teach content subjects in that language.

Since it would be unrealistic to expect teachers to reach a high level of professional language competence in an African language at this stage, it would be wiser to opt for comprehension. The needs of learners would be somewhat more effectively met if learners were at least able to be understood.

On the long-term, teaching of content subjects would require that the school have sufficient numbers of trained African teachers able to do so. It is therefore clear that it is not only language teachers who have to play a part in making South Africa a truly multilingual country. All teachers must form essential links in the chain. Providing mother tongue instruction for first-language speakers of African in at least some of the content subjects right 
up to grade twelve would be a way of ensuring that the value of multilingualism is honoured. Teaching speakers of high status languages at least one minority language is essential. There is an argument to be made that they should, in addition, receive some of their education through the medium of a minority language on the model of some of the Southern Californian schools. The assumption here is that the wider opportunity to use the language would have a strong effect on the proficiency they would attain. There could be a concomitant impact on the status of marginalised languages.

\section{THE OTHER LANGUAGES}

Thus far this article has been concerned only with the official languages. What of the languages spoken by other members of the population? And the so-called languages of trade, German, French, Chinese etc.? I think that the Australian model described by Smolicz and Secombe (1995) could provide South Africa with a very real possibility of not only catering for the small minority of indigenous languages, but maintaining those European languages that are learnt by every fewer pupils. Important as it is to cultivate our own languages, we dare not lose sight of the fact that we depend heavily on trade links with other countries, and language workers who are able to communicate with our trade partners and fill posts in foreign companies are a valuable asset which we must not neglect. Australia has introduced special language schools which can cater for a large number of languages. These centres are located in Melbourne, Sydney, Adelaide and other places that are easily accessible. The language offered there are considered part of the required subject load and progress reports are sent home to schools as well as parents at the end of each term. I think that this system could work just as well in South Africa, so serious consideration should be given to it. Parallel medium schools can cater for three languages at most. Depending on the demand, other languages could be taught at language centres, which like art centres, could serve the area rather than just one school.

True multilingualism would enable South Africa to avoid the pitfalls that other African countries have fallen into: pidginisation of English and the exclusion of the majority of the population form proper education, effective participation in government and access to the business sector (Van Staden 1997). Ironically, thought the rationale behind choosing English (a so-called neutral language) as a lingua franca is to avoid giving one language group advantage over others, it seems that that those who are fluent in English, for instance in Zambia where approximately $6,9 \%$ are in this position, do have a significant advantage over those who are not (Van Staden 1997). We would do well to take note of this in making decisions which are designed to create equity, not to entrench privilege.

\section{CONCLUSION}

Formulating a language policy is one thing - implementing it is quite another. Even it is the intention of the language policy makers to establish a truly multilingual country, where eleven official languages enjoy equal status, they could fail, because of the perception that exists at grassroots level that African languages are inferior. They do not give access to real power and real economic opportunities. Attempts to give mother-tongue instruction to speakers of 
African languages are perceived to be aimed at "confining them to an inferior position" (Phillipson 1992: 127).

Elevating the status of African languages in the eyes of school pupils could be a significant contribution towards establishing a truly multilingual society in South Africa in the future.

\section{REFERENCES}

BURLING, ROBBINS. 1981. Social constraints on adult language learning. In Winitz, Harris (Ed.), Native language and foreign language acquisition, Annals of the New York Academy of Sciences, Vol 379:279-290.

CUMMINS, J. 1991. Interdependence of first- and second-language proficiency in bilingual children. In Bialystok, $\mathrm{E}$ (Ed.). Language processing in bilingual children. Cambridge: Cambridge University Press.

DE KLERK, G. 1995. Bilingualism, the devil and the big wide world. In Heugh, K, Siegrühn, A and P Plüddemann (Eds), Multilingual education for South Africa. Johannesburg: Heinemann.

FISHMAN, JOSHUA A AND JOHN LOVAS. 1972. Bilingual education in a sociolinguistic perspective. In Spolsky, Bernard (Ed.), The Language Education of Minority Children. :Newbury House.

HOFFMAN, CHARLOTTE. 1991. An introduction to bilingualism. London and New York: Longman.

KRASHEN, STEPHEN. 1985. The input hypothesis: Issues and implications. London: Longman.

LAMBERT, WALLACE E. 1981. Bilingualism and language acquisition. Native and Foreign Language Acquisition, Annals of the New York Academy of Sciences, Vol. 10:3799-3822.

SINGLETON, DAVID. 1989. Language acqusition: the age factor. Multilingual Matters 47 . Clevedon: Multilingual Matters.

SMOLICZ, JERRY AND MARGARET SECOMBE. 1995. Teaching in many tongues: language schools in Australia. In Heugh, $\mathrm{K}$, Siegrühn, A and P Plüddemann (Eds), Multilingual education for South Africa. Johannesburg: Heinemann.

VAN STADEN, ELISE. 1997. Afrikaans, meertaiigheid en die rol van die universiteit, unpublished doctoral thesis, Rand Afrikaans University. 